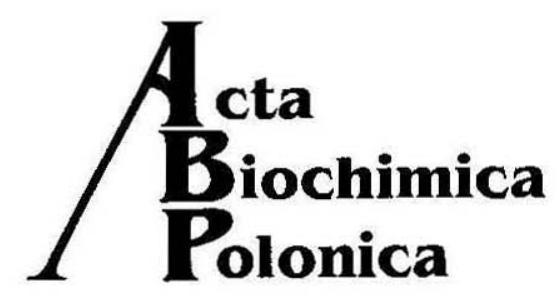

Vol. 42 No. 4/1995

$427-432$

QUARTERLY

Text of lecture presented at the 5th International Symposium on Molecular Aspects of Chemotherapy

\title{
Aza and diaza bioisosteric anthracene-9,10-diones as antitumor agents
}

\author{
A. Paul Krapcho ${ }^{a *}$, Martin J. Maresch ${ }^{a}$, Miles P. Hacker ${ }^{a}$, Ernesto Menta ${ }^{b}$, \\ Ambrogio Oliva ${ }^{b}$, Fernando C. Giuliani ${ }^{b}$ and Silvano Spinelli ${ }^{b}$ \\ ${ }^{a}$ Department of Chemistry, University of Vermont, Burlington, VT 05405 U.S.A. \\ ${ }^{b}$ Boehringer Mannheim Italia, Research Center, 20052, Milan, Italy
}

Key words: synthesis, antitumor agents, aza and diaza anthracene, 9,10-dione bioisosteres, structure vs activity, DNA-binding, topoisomerase II interactions

Synthetic routes to aza and diaza bioisosteres related to the anthracene-9,10-dione, mitoxantrone, have been developed. The antitumor properties of these chemotypes are compared with those exhibited by the corresponding carbocyclic analogues. The sensitivity of the expressed cytotoxicities on the position(s) of the nitrogen atom(s) are discussed in terms of potential cellular targets. Several analogues show potential for clinical evaluations.

The anthracene-9,10-dione chemotypes ametantrone (1a) and mitoxantrone (1b) are clinically used in the treatment of leukemias, lymphomas and in combination therapy for advanced breast and ovarian cancer [1,2]. The toxic side effects associated with the chemotherapeutic use of mitoxantrone (1b) are less pronounced than those exhibited by doxorubicin although myelotoxicity and cardiotoxicity are of clinical concern, especially in patients previously treated with doxorubicin [2].

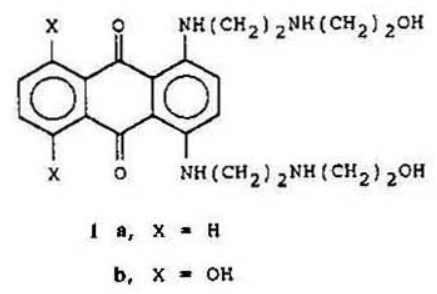

The need still exists for further studies of anthracene-9,10-dione congeners endowed with improved therapeutic efficacy, fewer toxic side effects, as well as effectiveness against drug resistant cell lines.
As in the anthracyclines, the cell killing events for the anthracene-9,10-dione are probably multimodal. Initial intercalation into DNA appears to be an important cellular event and this interaction may anchor the drugs at specific bases pair sites. This intercalated species can then disrupt DNA protein interactions, in particular, the interference of topoisomerase II [1, 3]. A few years ago our groups (University of Vermont and Boehringer Mannheim) launched a research effort to explore the effects of heteroatom substitution in the anthracene-9,10dione chromophore on antitumor activity. The initial studies dealt with aza and diaza bioisosteres related to the carbocylic models $\mathbf{1 a}$ and $\mathbf{1 b}$. These chemotypes would retain the same spatial and planar characteristics for host molecular recognition such as DNA interaction and could be endowed with properties for increasing the affinity of the drug for DNA and/or effecting interactions with topoisomerase II [4]. In addition, in contrast to the carbocyclic models, these heterocyclic analogues would be

*To whom correspondence should be addressed. 
much more readily reduced to anion-radicals and, therefore, be less prone to transfer an electron to molecular oxygen to produce undesirable radical species.

Towards these goals we have synthesized the azabioisosteres $2,3,4$, the $\mathrm{N}$-oxides 5 and the diazabioisosteres $6,7,8$. The antitumor data for these analogues are presented and discussed.

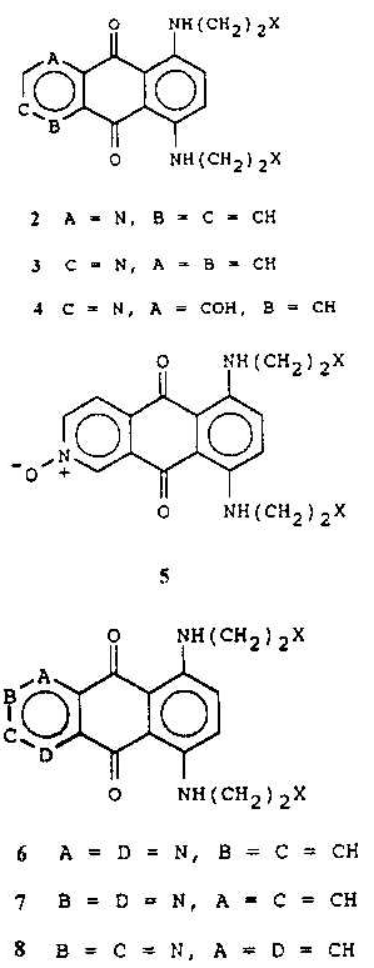

\section{SYNTHESIS}

In general, the aza bioisosteres $2[4,5]$ and 3 [6] were synthesized by $S_{N} A r$ displacements of the fluorides from 9 and 10, respectively, by
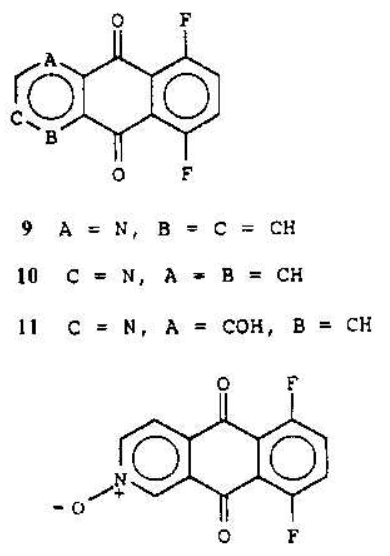

12

treatment with the appropriate aminoalkyl amine nucleophiles or aminoalkyl- $\mathrm{N}$-t-butoxy- carbonyl-amines (N-BOC-amines). The N-BOC analogues were then converted to the amine hydrochlorides by treatment with anhydrous hydrogen chloride.

The direct displacement of the fluorides from 11 to prepare analogues related to 4 was unsuccessful. This necessitated the conversion of $\mathbf{1 1}$ to the protected O-benzyl derivative, displacement of the fluorides with the appropriate amine nucleophile and removal of the benzyl groups by catalytic hydrogenation.

The analogues related to 5 were prepared by fluoride displacements from difluoro $\mathrm{N}$-oxide 12 with the appropriate amino nucleophile [6].

The diazabioisosteres $6,7,8$ were prepared in a similar pathway by displacements from 13, 14,15 , respectively, with the appropriate amino nucleophiles [7].

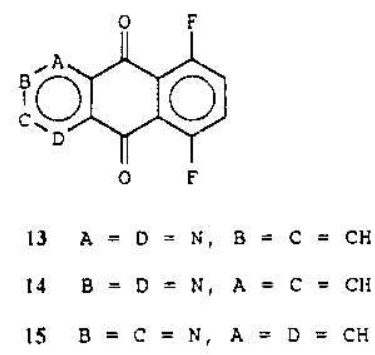

\section{BIOLOGICAL RESULTS}

\section{A. Aza bioisosteres}

(1) 6,9-Bis[(aminoalkyl)amino]benzo[g]quinoline-5,10-diones

The biological data [4] for some representative examples related to the 1 -aza chemotype 2 are presented in Table 1.

(2) 6,9-Bis[(aminoalkyl)amino]benzo[g]isoquinoline-5,10-diones

The in vitro biological activities against L1210 murine leukemia and a human colon adenocarcinoma cell line sensitive (LoVo) and resistant to doxorubicin (LoVo/Dx) [6] for selected aza bioisosteres 3 are presented in Table 2 .

Some in vivo data for analogue $3 \mathrm{~d}$ against $\mathrm{P} 388$ murine leukemia and a comparison with ametantrone (1a) are presented in Table 3.

The N-oxides $5 \mathbf{a}\left[\mathrm{X}=\mathrm{NH}_{2}\right]$ and $5 \mathbf{b}[\mathrm{X}=$ $\mathrm{N}\left(\mathrm{CH}_{3}\right)_{2}$ I exhibited ID $\mathrm{ID}_{50}$ values $(\mu \mathrm{g} / \mathrm{mL})$ of 7.3 and 0.44 , respectively, against the LoVo cell line and values of 62.6 and 2.6, respectively, against the LoVo/Dx cell line. 
(3) 4-Hydroxy-6,9-bis[(aminoalkyl)amino]benzoIg]isoquinoline-5,10-diones

Only two congeners $4 \mathbf{a}\left[\mathrm{X}=\mathrm{NH}_{2}\right]$ and $4 \mathbf{b}[\mathrm{X}$ $\left.\left.=\mathrm{N}\left(\mathrm{CH}_{3}\right)_{2}\right)\right]$ were evaluated in this series. The in vitro data against LoVo and LoVo/Dx along

Table 1

Biological activities of analogues of 2<smiles>[X]CNc1ccc(NCCN)c2c1C(=O)c1cccnc1C2=O</smiles>

2

\begin{tabular}{|c|l|c|c|c|}
\hline \multirow{2}{*}{$\begin{array}{c}\text { Struc- } \\
\text { ture }\end{array}$} & \multirow{2}{*}{$\underline{x}$} & \multicolumn{3}{|c|}{ L1210 Murine leukemia } \\
\cline { 3 - 6 } & & $\begin{array}{c}\text { In vitro } \\
\text { ID50 } \\
(\mu \mathrm{g} / \mathrm{mL})\end{array}$ & $\begin{array}{c}\text { In vivo } \\
(\mathrm{mg} / \mathrm{kg})\end{array}$ & $\begin{array}{c}\mathrm{T} / \mathrm{C}^{\mathrm{a}} \\
(\%)\end{array}$ \\
\hline 2a & $\mathrm{N}\left(\mathrm{CH}_{3}\right)_{2}$ & 0.16 & 50,25 & 130,120 \\
\hline 2b & $\mathrm{CH}_{2} \mathrm{~N}\left(\mathrm{CH}_{3}\right)_{2}$ & 1.7 & 50,25 & 116,106 \\
\hline 2c & $\mathrm{NH}_{2}$ & 1.5 & 20,25 & 106,114 \\
\hline 2d & $\mathrm{NH}\left(\mathrm{CH}_{2}\right)_{2} \mathrm{OH}$ & 5.8 & $25,12.5$ & 108,116 \\
\hline
\end{tabular}

${ }^{\mathrm{a}}$ Median survival time of treated mice/ (median survival time of controls) $\times 100$.

Table 2

In vitro cytotoxicities of analogues of 3<smiles>[X][Y2]CCNc1ccc(NCCC)c2c1C(=O)c1cnccc1C2=O</smiles>

3

\begin{tabular}{|c|l|c|c|c|}
\hline \multirow{2}{*}{$\begin{array}{c}\text { Com- } \\
\text { pounds }\end{array}$} & \multicolumn{2}{|c|}{$\boldsymbol{4}$} & \multicolumn{3}{|c|}{$\mathrm{ID} 50(\mu \mathrm{g} / \mathrm{mL})$} \\
\cline { 3 - 5 } & & L1210 & LoVo & $\begin{array}{c}\text { LoVo } \\
/ \mathrm{Dx}\end{array}$ \\
\hline $3 \mathrm{a}$ & $\mathrm{N}\left(\mathrm{CH}_{3}\right)_{2}$ & 0.006 & 0.08 & 0.13 \\
\hline $3 \mathrm{~b}$ & $\mathrm{NHCH}_{2} \mathrm{CH}_{3}$ & 0.01 & $-^{\mathrm{a}}$ & $-^{\mathrm{a}}$ \\
\hline $3 \mathrm{c}$ & $\mathrm{NH}\left(\mathrm{CH}_{2}\right)_{2} \mathrm{OH}$ & 0.06 & 1.3 & 99.5 \\
\hline $3 \mathrm{~d}(\mathrm{HCl})$ & $\mathrm{NH}_{2}$ & 0.01 & 0.24 & 7.2 \\
\hline $\begin{array}{c}\text { Ametan- } \\
\text { trone (1a) }\end{array}$ & - & 0.03 & 0.4 & 34.7 \\
\hline
\end{tabular}

${ }^{\mathrm{a}}$ Not determined. with comparative data for $3 \mathrm{~d}$ and mitoxantrone (1b) are tabulated in Table 4.

Analogues $\mathbf{4 b}$ and $\mathbf{3 a}$ exhibited $\mathrm{ID}_{50}$ values $(\mu \mathrm{g} / \mathrm{mL})$ of 0.0015 and 0.006 , respectively, in the L1210 murine leukemia screen.

Table 3

In vivo antitumor activities of $3 d$ and $1 b$ against P388 murine leukemia
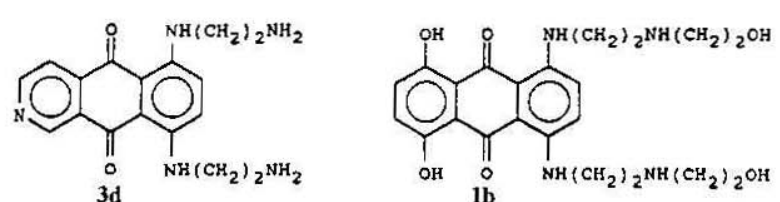

\begin{tabular}{|c|c|c|}
\hline Compound & $\begin{array}{c}\text { Dose }^{\mathrm{a}}(\mathrm{mg} / \mathrm{kg} \\
\text { per day) }\end{array}$ & $\mathrm{T} / \mathrm{C}^{\mathrm{b}}(\%)$ \\
\hline 3d (maleate) & 8 & 162 \\
\hline & 12 & 170 \\
\hline & 18 & 206 \\
\hline & 22 & 250 \\
\hline & 27 & 230 \\
\hline & 2 & 172 \\
\hline & 3 & 196 \\
\hline & 4 & 175 \\
\hline
\end{tabular}

${ }^{\mathrm{a}} 10^{6}$ cells/mouse iv in CD2F1. Treatment iv on days $1,4,7$ after tumor transplantation (day 0 ).

${ }^{\mathrm{b}}$ See footnote a in Table 1.

Table 4

In vitro activities of $3 d, 4 a$ and mitoxantrone against LoVo and LoVo/Dx cells.
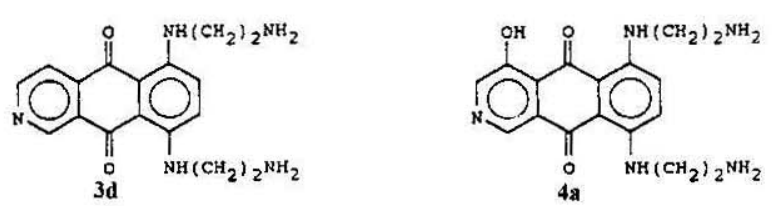

\begin{tabular}{|l|l|c|c|}
\hline \multirow{2}{*}{ Compound } & \multicolumn{3}{|c|}{ Dose } \\
& \multicolumn{3}{|c|}{ ID50 $(\mu \mathrm{g} / \mathrm{mL})$} \\
\cline { 2 - 4 } & LoVo & LoVo/Dx & $\mathrm{RI}^{\mathrm{a}}$ \\
\hline 3d (maleate) & 0.24 & 7.2 & 30 \\
\hline 4a (HCl) & 0.1 & 0.7 & 7 \\
\hline Mitoxantrone (1b) & 0.009 & 0.25 & 28 \\
\hline
\end{tabular}

${ }^{\mathrm{a}}$ Resistance index. 
The in vivo data against $\mathrm{P} 388$ murine leukemia for $\mathbf{4 a}$ and $\mathbf{3 d}$ are listed in Table 5.

Table 5

Comparison of antitumor activites of $3 d$ and $4 a$ against P388 murine leukemia
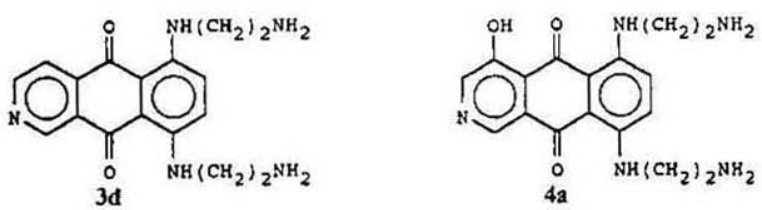

\begin{tabular}{|l|c|c|}
\hline Compound & $\begin{array}{c}\text { Dose }^{\mathrm{a}}(\mathrm{mg} / \mathrm{kg} \\
\text { per day) }\end{array}$ & ${\mathrm{T} / \mathrm{C}^{\mathrm{b}}(\%)}$ \\
\hline 3d (maleate) & 8 & 162 \\
\hline & 12 & 170 \\
\hline & 18 & 206 \\
\hline $\mathbf{4 a}$ & 22 & 250 \\
\hline & 0.6 & 158 \\
\hline & 0.8 & 179 \\
\hline & 1.3 & 216 \\
\hline Mitoxantrone (1b) & 2 & 167 \\
\hline & 2 & 122 \\
\hline & 3 & 197 \\
\hline
\end{tabular}

${ }^{\text {a }}$ See footnote a in Table 3.

${ }^{b}$ See footnote $a$ in Table 1.

\section{Diaza bioisosteres}

(1) 6,9.Bis(aminoalkyl)amino]benzo[g]quinoxalin:-5,10-diones

Three representative examples of congeners 6 [7] were evaluated against LoVo and LoVo/Dx. Congeners 6a $\left[X=\mathrm{N}\left(\mathrm{CH}_{3}\right)_{2}\right], 6 b[X$ $\left.=\mathrm{CH}_{2} \mathrm{NH}_{2}\right]$ and $6 \mathrm{c}\left[\mathrm{X}=\mathrm{NH}_{2}\right.$, maleate salt $]$ were found to be devoid of in vitro cytotoxicity against these cell lines. These analogues were also found to be inactive in the L1210 murine leukemia cell line with $\mathrm{ID}_{50}$ values $(\mu \mathrm{g} / \mathrm{mL})$ of $4.2,>10$, and $>10$, respectively. Chemotypes $6 a$ and $6 \mathbf{b}$ were also inactive in vivo against P388 murine leukemia.

(2) 6,9-Bis[aminoalkyl)amino]benzo[g]quinazoline-5,10-diones

The synthesis of only one of these diaza bioisosteres 7 [7] was successful from the $\mathrm{S}_{\mathrm{N}} \mathrm{Ar}$ displacements of the fluorides in 14. Competing side reactions involving pyrimidine ring opening thwarted this displacement process. Against L1210, S180 and S180/A10 cell lines, 7a $\left[\mathrm{X}=\mathrm{N}\left(\mathrm{CH}_{3}\right)_{2}\right.$ ] exhibited ID $50(\mu \mathrm{g} / \mathrm{mL})$ values of $0.31,3.5$ and $>10$, respectively. No in vivo studies were performed on this bioisostere.

(3) 6,9-Bis[(aminoalkyl)amino]benzo[g]phthalazine-5,10-diones

The bioisosteres $8 \mathrm{a}\left[\mathrm{X}=\mathrm{N}\left(\mathrm{CH}_{3}\right)_{2}\right]$ and $\mathbf{8 b}[\mathrm{X}$ $\left.=\mathrm{NH}_{2}\right]$ were screened in an L1210 assay and had $\mathrm{ID}_{50}$ values $(\mu \mathrm{g} / \mathrm{mL})$ of 0.37 and 2.5 , respectively. Both $\mathbf{8 a}$ and $\mathbf{8 b}$ were evaluated against LoVo and LoVo/Dx. Against LoVo 8a and $8 \mathrm{~b}$ showed $\mathrm{ID}_{50}$ values $(\mu \mathrm{g} / \mathrm{mL})$ of 0.86 and 2.8 , respectively. In the LoVo/Dx screen $8 \mathrm{a}$ and $8 b$ had ID ${ }_{50}$ values of 1.84 and 2.2 , respectively. These two compounds were devoid of antitumor activity in vivo against P388 murine leukemia.

Biological data comparisons of aza and diaza bioisosteres

Comparative data for the bioisosteres bearing the same side arms are presented in Table 6.

Table 6

Effect of the positioning of the $N$-atom(s) on the in vitro cytotoxicity of 5,8-bis-[2-(dimethylamino)ethyllamino]aza- and diazaanthracene-9,10-diones against $L 1210$ cells

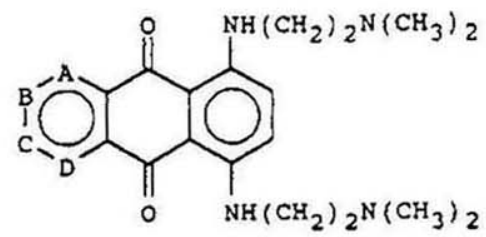

\begin{tabular}{|c|l|l|c|c|c|}
\hline $\begin{array}{c}\text { Copm- } \\
\text { pound }\end{array}$ & \multicolumn{1}{|c|}{$\mathrm{A}$} & $\underline{\mathrm{B}}$ & $\underline{\mathrm{C}}$ & $\underline{\mathrm{D}}$ & $\begin{array}{c}\text { ID50 } \\
(\mu \mathrm{g} / \mathrm{mL})\end{array}$ \\
\hline- & $\mathrm{CH}$ & $\mathrm{CH}$ & $\mathrm{CH}$ & $\mathrm{CH}$ & 0.08 \\
\hline $2 \mathrm{a}$ & $\mathrm{N}$ & $\mathrm{CH}$ & $\mathrm{CH}$ & $\mathrm{CH}$ & 0.16 \\
\hline $3 \mathrm{a}$ & $\mathrm{CH}$ & $\mathrm{N}$ & $\mathrm{CH}$ & $\mathrm{CH}$ & 0.0064 \\
\hline $4 \mathrm{~b}$ & $\mathrm{COH}$ & $\mathrm{CH}$ & $\mathrm{N}$ & $\mathrm{CH}$ & 0.002 \\
\hline $6 \mathrm{a}$ & $\mathrm{N}$ & $\mathrm{CH}$ & $\mathrm{CH}$ & $\mathrm{N}$ & 4.2 \\
\hline $7 \mathrm{a}$ & $\mathrm{N}$ & $\mathrm{CH}$ & $\mathrm{N}$ & $\mathrm{CH}$ & 0.31 \\
\hline $8 \mathrm{a}$ & $\mathrm{CH}$ & $\mathrm{N}$ & $\mathrm{N}$ & $\mathrm{CH}$ & 0.37 \\
\hline
\end{tabular}




\section{DISCUSSION}

An examination of the data presented in Tables 1 and 2 indicates that those analogues with the nitrogen at position 2 are more active than the comparative models with the same side arms but with the nitrogen atom at position 1 . Compound 3d (maleate salt) shows good in vitro activity against LoVo and LoVo/Dx (Table 3).

The $\mathrm{N}$-oxide 5 a displayed little in vitro activity (LoVo) but significant in vivo activity against P388 murine leukemia. This is perhaps suggestive of a bioactivation by deoxygenation to yield 3d.

The results of Tables 4 and 5 show good in vitro and in vivo activities for $3 \mathrm{~d}$ and $\mathbf{4 a}$. The presence of a hydroxy group at position 2 in the 2-aza series shows a modest increase in activity when compared with models divorced of this hydroxy substitution (Table 4).

The side arms in the 2-aza series for maximum activity are not identical to those present in ametantrone (1a) or mitoxantrone (1b).

The diaza analogues, in general, exhibit poor antitumoral activities in most of the screens in which they were evaluated (comparisons of data in Table 6).

Studies to rationalize the remarkable antitumor sensitivity to the position of the nitrogen atom have been commenced. In particular, the 1-aza analogue $2 \mathrm{c}$ and the 2 -aza analogue $3 \mathrm{~d}$ have been examined. Spectral shifts and gel mobilities have been evaluated in order to ascertain the relationship between DNA binding and cytotoxicity. The DNA affinity was 5-10 times higher for the 2-aza analogues. This cannot account for the differences in cytotoxicity. The cytotoxicity differences for the two series does not correlate with DNA damage or topoisomerase II interactions [8].

\section{CONCLUSIONS}

Aza bioisostere 3d (maleate salt) (BBR 2778) is not cardiotoxic and at equiactive doses, less leukopenic than mitoxantrone (1b). It appears to be a favorable candidate for clinical evaluation.

\section{REFERENCES}

1. Krapcho, A.P., Getahun, Z., Avery, K.L., Jr., Vargas, K.J., Hacker, M.P., Spinelli, S., Pezzoni, G. \& Manzotti, C. (1991) Synthesis and antitumor evaluations of symmetrically and unsymmetrically substituted 1,4-bis[(aminoalkyl)aminolanthracene-9,10-diones and 1,4-bis[(aminoalkyl)amino]-5,8-dihydroxyanthraene-9,10-diones. J. Med. Chem. 34, 23732380, and references cited therein.

2. Faulds, D., Balfour, J.A., Chrisp, P. \& Langtry, H.D. (1991) Mitoxantrone. A review of its pharmacodynamic and pharmacokinetic properties, and therapeutic potential in the chemotherapy of cancer. Drugs 41, 400-449.

3. Lown, J.W. (ed.) (1988) Bioactive molecules. anthracycline and anthracenedione-based anticancer agents; vol. 6, Elsevier, New York.

4. Krapcho, A.P., Landi, J.J., Jr., Hacker, M.P. \& McCormack, J.J. (1985) Synthesis and antineoplastic evaluations of 5,8-bis[(aminoalkyl)amino]-1-aza-anthracene-9,10-diones. J. Med. Chem. 28, 1124-1126, and references cited therein.

5. Krapcho, A.P., Petry, M.E., Landi, J.J., Jr., Stallman, J., Polsenberg, J.F., Hacker, M.P., Spinelli, S., Oliva, A., Di Domenico, R. \& Menta, E. (1993) The synthesis of 6,9-difluorobenzoIg]quinoline-5,10-dione. Displacements of the fluorides by diamines which lead to 6,9bis[(aminoalkyl)amino]benzo[g]quinoline-5,10 -diones. J. Heterocyclic Chem. 30, 1565-1569.

6. Krapcho, A.P., Petry, M.E., Getahun, Z., Landi, J.J., Jr., Stallman, J., Polsenberg, J.F., Gallagher, C.E., Maresch, M., Hacker, M.P., Giuliani, F.C., Beggiolin, G., Pezzoni, G., Menta, E., Manzotti, C., Oliva, A., Spinelli, S. \& Tognella, S. (1994) 6,9-Bis[(aminoalkyl)amino]benzo[g]isoquinoline-5,10-diones. A novel class of chromophore modified antitumor anthracene-9,10-diones: synthesis and antitumor evaluations. J. Med. Chem. 37, 828-837.

7. Krapcho, A.P., Maresch, M., Helgason, A.L., Rosner, K.E., Hacker, M.P., Spinelli, S., Menta, E. \& Oliva, A. (1993) The synthesis of 6,9-bis[(aminoalkyl)amino] substituted benzo[g]quinoxaline-, benzo[g]quinazoline- and benzolglphthalazine-5,10-diones via regiospecific displacements. J. Heterocyclic Chem. 30, 1597-1606.

8. Zwelling, L.A., Mayes, J., Altschuler, E., Satitunwaycha, P., Tritton, T.R. \& Hacker, M.P. (1993) Activity of two novel anthracene- 
-9,10-diones against human leukemia cells containing intercalator-sensitive or -resistant forms of topoisomerase II. Biochem. Pharmacol. 46, 265-271. 